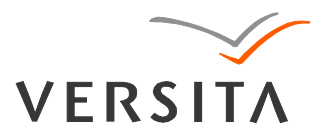

GEOCHRONOMETRIA 41(4) 2014: 369-376

DOI 10.2478/s13386-013-0164-Z

Available online at

www.springerlink.com

\title{
SEDIMENT GEOCHRONOLOGY AND SPATIO-TEMPORAL AND VERTICAL DISTRIBUTIONS OF RADIONUCLIDES IN THE UPPER BONNY ESTUARY (SOUTH NIGERIA)
}

\author{
OMOROTIONMWAN OMOKHEYEKE ${ }^{1}$, FRANCIS D. SIKOKI ${ }^{1}$, ABDELMOURHIT LAISSAOUI ${ }^{3}$, \\ DAVID AKPULUMA ${ }^{2}$, PETER O. ONYAGBODOR ${ }^{2}$, AZZOUZ BENKDAD ${ }^{3}$ and MONCEF BENMANSOUR ${ }^{3}$ \\ ${ }^{I}$ Department of Animal and Environmental Biology Faculty of Science University of Port Harcourt, Port Harcourt, Nigeria \\ ${ }^{2}$ Centre for Marine Pollution Monitoring and Seafood Safety, University of Port Harcourt, Port Harcourt, Nigeria \\ ${ }^{3}$ Centre National de L'Energie, des Sciences et des Techniques Nucléaires (CNESTEN), B.P. 1382, R.P. 10001, Rabat, Morocco
}

Received 27 December 2013

Accepted 8 April 2014

\begin{abstract}
Surface deposits and sediment cores were collected from the Upper Bonny Estuary, located in Southwest Nigeria, and analyzed to determine spatio-temporal and vertical distributions of radionuclide activities expressed in $\mathrm{Bq} \cdot \mathrm{kg}^{-1}$ dry weight. The results of activities of naturally occurring radionuclides of ${ }^{226} \mathrm{Ra}\left(15 \pm 2-34 \pm 3 \mathrm{~Bq} \cdot \mathrm{kg}^{-1}\right),{ }^{228} \mathrm{Ra}\left(32 \pm 5-48 \pm 6 \mathrm{~Bq} \cdot \mathrm{kg}^{-1}\right),{ }^{40} \mathrm{~K}(264 \pm 29-$ $462 \pm 36 \mathrm{~Bq} \cdot \mathrm{kg}^{-1}$ ) were found to be all within the range of typical values reported for coastal regions. Ratios of ${ }^{226} \mathrm{Ra}$ to ${ }^{228} \mathrm{Ra}$ suggested accretion for all samples with low sediment accumulation registered during rainy months. In addition, vertical distributions at the three sampling sites were also studied with the initial aim of establishing chronologies from the decay of excess ${ }^{210} \mathrm{~Pb}$. In two cores, excess ${ }^{210} \mathrm{~Pb}$, estimated by subtracting ${ }^{226} \mathrm{Ra}$ from total ${ }^{210} \mathrm{~Pb}$ on a layer-by-layer basis, exhibit relatively constant activity with discrete minima and maxima. Therefore, these cores were excluded from radiometric dating. Only the third core could be dated by the constant rate of supply model, and ${ }^{137} \mathrm{Cs}$ was utilized to validate the ${ }^{210} \mathrm{~Pb}$ chronology.
\end{abstract}

Keywords: The Bonny Estuary, Nigeria, gamma and alpha spectrometry, ${ }^{210} \mathrm{~Pb},{ }^{137} \mathrm{Cs}$, sediment dating, CRS model.

\section{INTRODUCTION}

The Niger delta region of Nigeria is bounded to the south by the Atlantic Ocean. It covers about $50 \%$ of the total length of the Nigerian Coastline and it is situated in the Gulf of Guinea, located between $5^{\circ} \mathrm{E}$ to $8^{\circ} \mathrm{E}$ longitude and $4^{\circ} \mathrm{N}$ to $6^{\circ} \mathrm{N}$ latitude. It is the largest wetland in Africa and the third largest in the world consisting of flat low lying swampy terrain that is criss-crossed by meandering and anastomosing streams, rivers and creeks.

Corresponding author: A. Laissaoui

e-mail: laissaoui@cnesten.org.ma
However, this ecosystem is under threat from pollutants generated by oil and gas related installations, including flow stations, oil well heads, loading terminals and tank farms.

The Bonny Estuary is one of the numerous low land coastal rivers of the Niger Delta Complex (Fig. 1). It is located between $4^{\circ} 25^{\prime}$ and $4^{\circ} 50^{\prime \prime} \mathrm{N}$ latitude and $7^{\circ} 00^{\prime}$ and $7^{\circ} 15^{\prime}$ E longitude in River State, Nigeria. Like most other rivers in this region, it is short, extending to approximately $180 \mathrm{~km}$ from its mouth. It is mainly blackish with very little freshwater discharge, mostly from the New Calabar river system, and consists of a main river channel 


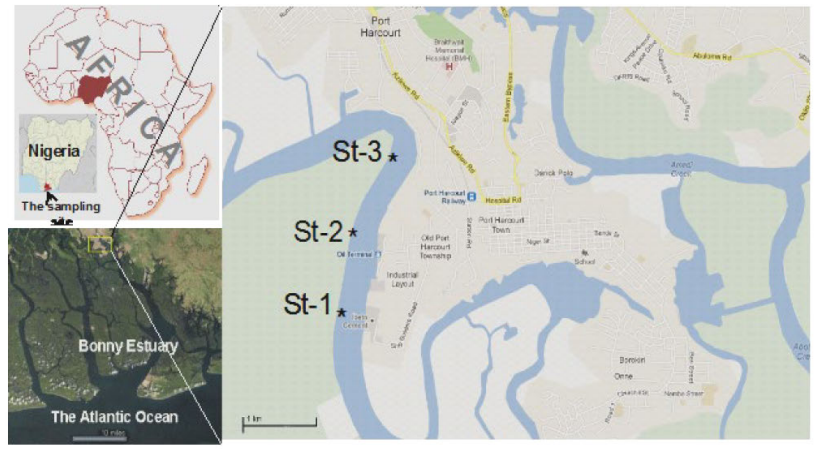

Fig. 1. Map of the study area showing the sampling locations. Insets are also presented showing the location of Nigeria in Africa and the position of the study area within the whole Bonny Estuary.

and a large number of associated creeks and creek-lets. The Bonny Estuarine system (maximum width of $2 \mathrm{~km}$ and maximum depth of approximately $15 \mathrm{~m}$ near the mouth) has the largest tidal volume of all river system in the Niger Delta and it is mostly affected by tidal movement. The climate of the study area, located in the upper part of the Bonny Estuary, is tropical and marked by two distinct seasons, the dry season (November - March) and the wet season (April - October). A study on water quality in the Upper Bonny Estuary is presented in Inyang et al. (2011).

Only few studies related to naturally occurring radionuclide activities in some environmental matrices have been conducted in coastal areas in Nigeria. Radionuclides, mainly gamma emitters such as ${ }^{40} \mathrm{~K},{ }^{226} \mathrm{Ra}$ and ${ }^{232} \mathrm{Th}$ have been measured recently in soil, sediment and water (Farai et al., 2006; Arogunjo et al., 2009 and Agbalagba and Anoja, 2011). Activities of ${ }^{40} \mathrm{~K},{ }^{238} \mathrm{U}$ and ${ }^{232} \mathrm{Th}$ radionuclides were measured in soil samples around the coastal area in Nigeria (Alatise et al., 2008). Results from this work were seriously criticised and qualified as being impossible and improperly determined (Leopold and Gerstmann, 2009).

Sediments in estuarine systems have been considered as the final fate of radionuclides, among other pollutants, and, therefore, their analysis provide more reliable assessment of radioactive pollution than that of water (Laissaoui et al., 2013). The reason is that the rate of change of pollutant concentrations in sediment is extremely slower than in water. Furthermore, profiles of radionuclides, such as ${ }^{210} \mathrm{~Pb}$ and ${ }^{137} \mathrm{Cs}$, are commonly used for quantifying sediment accumulation rates and deposition dates as a function of depth. Such methodology has shown, during the last decades, its usefulness in establishing chronologies of contaminant inputs and sediment dynamics in natural aquatic systems over the past 100-150 years (Appleby, 2008; Begy et al., 2011 and Szczepańska et al., 2012). This work, which was conducted within the framework of an IAEA regional project, had several objectives. First, we sought to determine levels of radio- nuclide activities in sediment samples from the Upper Bonny Estuary, an area with no existing radiological data, using low level gamma and alpha spectromeries. Second, we studied the spatial and temporal variations of naturally occurring radionuclides, and explored their vertical distributions in three sediment cores collected from sites of diverse sedimentary characteristics. Dating sediment using the unsupported ${ }^{210} \mathrm{~Pb}$ and the Constant Rate of Supply model was applied for establishing age/depth and mass accumulation rate/depth relationships.

\section{MATERIAL AND METHODS}

\section{Sampling and samples treatment}

Sediment cores were retrieved from shallow marginal areas at three stations belonging to the upper Bonny Estuary in August 2011 using an Uwitec gravity corer of $10 \mathrm{~cm}$ internal diameter. Sampling locations are shown in Fig. 1. An early study on textural characteristics of sediments reported that the channel centre is mainly fine and coarse sands, while silt and clay are predominant in marginal areas $(60-100 \%)$ characterised by weak tidal currents which promote the deposition of fine sediment (Dublin-Green, 1985). Two cores, $32 \mathrm{~cm}$ and $30 \mathrm{~cm}$ depth, were collected from station 1 (St-1) and station 2 (St-2) respectively located downstream of the Bonny Estuary. This area is characterised by intensive human activity (navigation, fishing and land-based industrial and commercial facilities). The core from station 3 (St-3) was only $20 \mathrm{~cm}$ depth and was retrieved from a relatively low energy environment on the left bank of the river. In addition, sediment surface samples $(6 \mathrm{~cm}$ depth) were also collected, using a PVC tube of $10 \mathrm{~cm}$ internal diameter, from the three stations during different months (August, October and December 2011, and February and May 2012) covering rainy and dry seasons.

The sediment cores were immediately transported after retrieval to the laboratory for pre-treatment and conditioning prior to radiometric analyses. Each core was sectioned into $2 \mathrm{~cm}$ slices and wet sub-samples were weighed and then dried in an oven, using a constant temperature of $80^{\circ} \mathrm{C}$ during $24 \mathrm{~h}$. Dry samples were weighed again and the content of water in each stratigraphic level was calculated for the three cores. Bulk densities were determined from water content and particle density of each slice. Finally, dried sediment was ground in a mortar to fine powder and homogenised for subsequent alpha and gamma emitters analyses. Organic matter content was calculated as the difference in weight between the dried sediment and the ash obtained following ignition at $550^{\circ} \mathrm{C}$ for $24 \mathrm{~h}$.

\section{Radiometric measurements}

Activity of ${ }^{210}$ Po was determined more than a year after sampling, so it was assumed that secular equilibrium with its parent ${ }^{210} \mathrm{~Pb}$ had been achieved. Therefore, it was 
only possible to determine total ${ }^{210} \mathrm{~Pb}$ activities at the sampling date. An aliquot of about $0.5 \mathrm{~g}$ of dry sediment was weighed in an acid cleaned beaker, spiked with a known activity of ${ }^{209} \mathrm{Po}$ yield tracer (the certified activity concentration is $0.357 \pm 0.011 \mathrm{~Bq} \cdot \mathrm{g}^{-1}$ ) and totally digested using concentrated nitric and perchloric acids. A review of ${ }^{210}$ Po determination can be seen in Mathews et al. (2007). The digested sample was evaporated to almost dryness and treated by evaporation with concentrated hydrochloric acid three times and, finally, dissolved in $80 \mathrm{ml}$ of $0.5 \mathrm{~N} \mathrm{HCl}$. About $50 \mathrm{mg}$ of ascorbic acid was added to reduce any iron present in the solution. Polonium was auto-deposited onto a Platinum coated disc for 6 hours of heating at $80^{\circ} \mathrm{C}$ and stirring of the solution. The prepared alpha-sources were analysed by alpha-ray spectrometry using silicon surface barrier detectors (EG\&G) coupled to a PC running Maestro ${ }^{\mathrm{TM}}$ data acquisition software. The chemical recovery values ranged from 60 to $90 \%$.

Gamma emitting radionuclides $\quad\left[{ }^{228} \mathrm{Ac}\left({ }^{228} \mathrm{Ra}\right)\right.$, ${ }^{214} \mathrm{Bi}\left({ }^{226} \mathrm{Ra}\right),{ }^{212} \mathrm{~Pb}\left({ }^{228} \mathrm{Th}\right)$ and $\left.{ }^{40} \mathrm{~K}\right]$ were measured using gamma-ray spectrometer. The detector was a low background CANBERRA high-purity germanium p-type coaxial detector, housed in a $10 \mathrm{~cm}$ thick high-purity lead shield. The relative efficiency was $30 \%$ and the resolution was $2 \mathrm{keV}$ for the $1332 \mathrm{keV}{ }^{60} \mathrm{Co} \gamma$-peak. Weighed samples were introduced into $20 \mathrm{ml}$ nalgene containers and sealed to trap the gaseous ${ }^{222} \mathrm{Rn}$ and ${ }^{220} \mathrm{Rn}$ emanating from in-situ ${ }^{226} \mathrm{Ra}$ and ${ }^{224} \mathrm{Ra}$, respectively. The flasks were stored for more than 21 days and then counted for 24 hours each one. In some cases, and due to the small quantities of sediment in the upper layers of each core, we combined two to three adjacent sub-samples to reach the working geometry. ${ }^{226} \mathrm{Ra}$ activity was obtained from the ${ }^{214} \mathrm{Bi}$ photopeak at $609.3 \mathrm{keV}$. Due to the low activity of ${ }^{137} \mathrm{Cs}$ and the low amounts of sub-samples (around $20 \mathrm{~g}$ ), a detector of HPGe of relative efficiency $70 \%$ was used for the determination of this radionuclide in each stratigraphic level. Energy and efficiency calibrations of the gamma spectrometers were carried out using a multigamma source provided by Amersham and consisting of a mixture radionuclides emitting, each one, one or two $\gamma$ rays in the energy range of $150-1800 \mathrm{keV}$. A known amount of the standard solution was diluted in the same geometry as the samples. The activity concentration (in $\mathrm{Bq} \cdot \mathrm{kg}^{-1}$ ) in each sample of all the studied radionuclides was determined from the net peak area, detector efficiency, gamma intensity and sample weight. The analytical procedure was checked using reference material (IAEA$327)$. Good agreement $(>90 \%)$ was found between measured and certified values for ${ }^{214} \mathrm{Bi},{ }^{228} \mathrm{Ac}$ and ${ }^{40} \mathrm{~K}$.

\section{RESULTS AND DISCUSSION}

\section{Surface samples (spatial and temporal trends)}

Spatial and temporal variations of radium isotopes concentrations $\left({ }^{226} \mathrm{Ra}\right.$ and $\left.{ }^{228} \mathrm{Ra}\right)$ are plotted in Fig. 2 . ${ }^{228} \mathrm{Ra}$ showed a fairly uniform distribution among locations and months (within error range), while ${ }^{226} \mathrm{Ra}$ displayed some variability with almost usually lower activity concentrations in dry months (February and December) than in rainy months (May, August and October). The highest values were registered during rainy months which could be attributable to the incorporation of ${ }^{226} \mathrm{Ra}$ - enriched particles eroded from the surrounding drainage area to the sediment.

Total ${ }^{210} \mathrm{~Pb}$ in surface samples was determined via its daughter ${ }^{210} \mathrm{Po}$ by alpha spectrometry assuming that the secular equilibrium between both radionuclides was achieved. Activity concentrations, corrected to the sampling dates, are plotted in Fig. 3. The activities in St-3 were found lower than those in St-1 and St-2 with the lowest activity $\left(56 \pm 6 \mathrm{~Bq} \cdot \mathrm{kg}^{-1} \mathrm{dw}\right)$ registered in the sample collected in December (dry month). The unsupported component of ${ }^{210} \mathrm{~Pb}$ in estuarine sediment has two sources: the atmospheric, which should be the same for the three stations due to their proximity from each other, and sedimentation of ${ }^{210} \mathrm{~Pb}$ adsorbed onto particles delivered by the river inputs and/or dredging activities. Therefore, low sedimentation rate in St-3 could be behind the low ${ }^{210} \mathrm{~Pb}$ activity concentration in surface sediment.

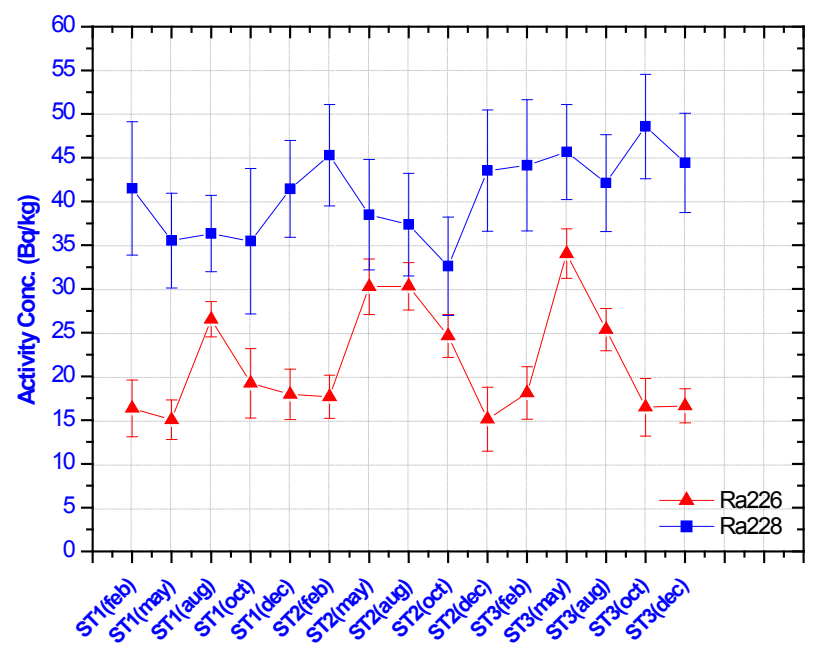

Fig. 2. Activity concentrations of ${ }^{226} \mathrm{Ra}$ and ${ }^{228} \mathrm{Ra}$ in different months at the three stations. Activities are in $B q . \mathrm{kg}^{-1} \mathrm{dry}$ weight and uncertainties are $1-\sigma$ statistical errors. Variation of ${ }^{226} \mathrm{Ra}$ to ${ }^{228} \mathrm{Ra}$ ratio is also plotted. 


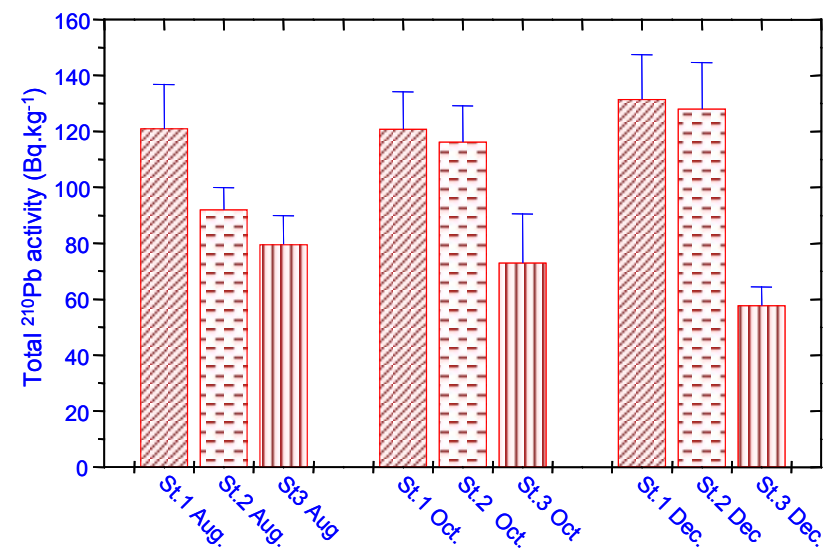

Fig. 3. Spatio-temporal distribution of total ${ }^{210} \mathrm{~Pb}\left(\mathrm{~Bq} \cdot \mathrm{kg}^{-1}\right.$, dry weight) in surface sediment from the Bonny Estuary.

${ }^{40} \mathrm{~K}$ is a radionuclide which is indicative of finegrained clay sediments found in harbour and channel environments (Noakes, 2003). The values of ${ }^{40} \mathrm{~K}$ found in the surface samples, collected in different months, ranged between $264 \pm 29$ and $462 \pm 36 \mathrm{~Bq} \cdot \mathrm{kg}^{-1}$ dry weight, displaying moderate variability among months and stations. The values were within the range of typical values found in worldwide coastal environments (UNSCEAR, 2000). The averaged activity concentration over months were $388 \pm 89 \mathrm{~Bq} \cdot \mathrm{kg}^{-1}$ for St-2 and St-3, and $326 \pm 90 \mathrm{~Bq} \cdot \mathrm{kg}^{-1}$ for St-1. Therefore, there are no significant enhanced concentrations, within error ranges, of this radionuclide that could identify preferential sites and/or months for deposition of particles.

\section{Vertical distributions}

The above studied radionuclides for surface sediment samples were also assessed in the sub-samples of each one of the three cores with depth. Activity concentrations of ${ }^{228} \mathrm{Ac}\left({ }^{228} \mathrm{Ra}\right),{ }^{212} \mathrm{~Pb}\left({ }^{228} \mathrm{Th}\right)$ and ${ }^{40} \mathrm{~K}$ vs depth in sediment are plotted in Fig. 4. It should be noted that ${ }^{228} \mathrm{Th}$ and ${ }^{228} \mathrm{Ra}$ activities are almost equal to one another within each layer $\left({ }^{228} \mathrm{Th} /{ }^{228} \mathrm{Ra}\right.$ activity ratios range from $0.95 \pm 0.08$ to $1.02 \pm 0.08$ for St- 1 , from $0.86 \pm 0.17$ to $1.02 \pm 0.19$ for St-2 and from $0.94 \pm 0.12$ to $1.01 \pm 0.16$ for St-3), which means that these two radionuclides are within error ranges in secular equilibrium at the study site. The profiles of Fig. 4 displayed fairly homogenous distributions throughout the cores with the only exception for ${ }^{40} \mathrm{~K}$ in St-3. A relatively visible increase of this radionuclide activity in the basal $6 \mathrm{~cm}$ of the core was observed. This enhancement of ${ }^{40} \mathrm{~K}$ may be attributed to the different origin of particles present in the deepest layers of the core that, thus, may contain more fine-grained clay sediment than the rest of the core. Vertical distributions of organic matter content are also depicted in Fig. 4 for each coring site.

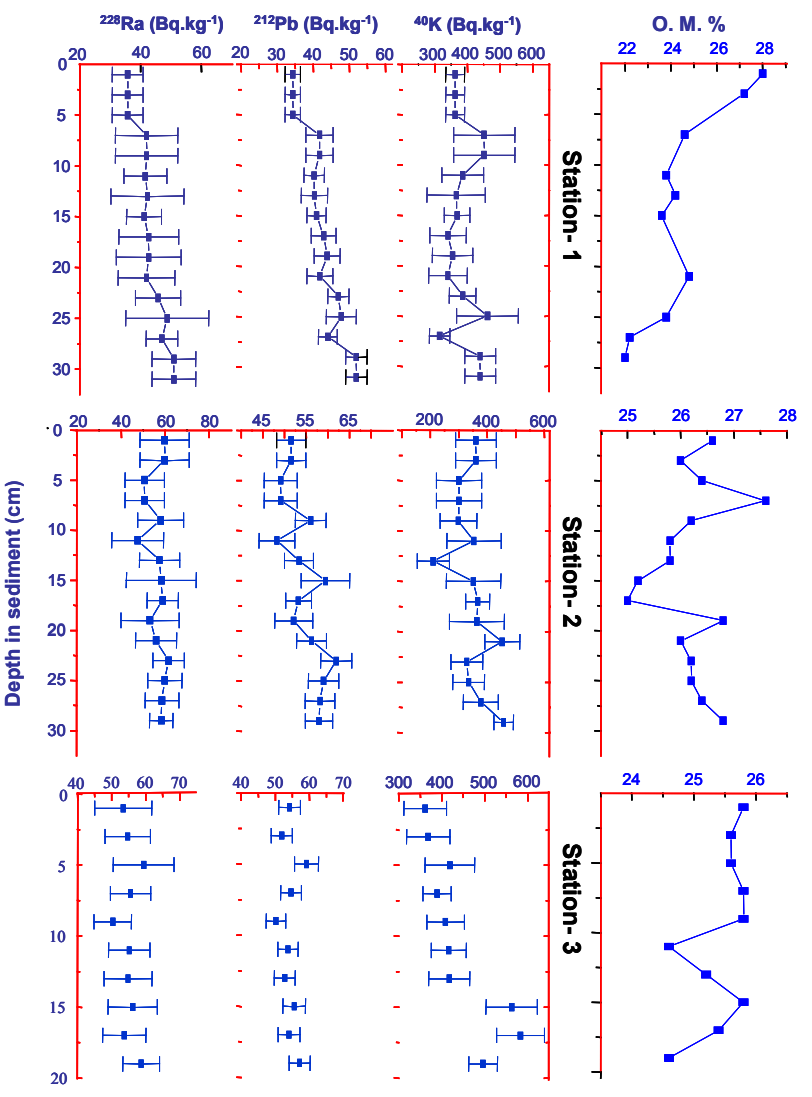

Fig. 4. Vertical distributions of ${ }^{228} \mathrm{Ra},{ }^{212} \mathrm{~Pb}$ and ${ }^{40 \mathrm{~K}}$ in the three sediment cores collected from the Bonny Estuary. Activities are in $\mathrm{Bq} \cdot \mathrm{kg}^{-1}$ dry weight and errors are 1- $\sigma$ statistical uncertainties.

The total ${ }^{210} \mathrm{~Pb}$ and ${ }^{226} \mathrm{Ra}$ activities throughout the three cores were determined (Fig. 5) with the aim to carry out radiometric dating. Vertical distributions corresponding to St-1 and St-2 did not exhibit significant decrease in ${ }^{210} \mathrm{~Pb}$ with depth, but rather relatively constant activities with discrete maxima and minima. Unsupported lead-210 $\left({ }^{210} \mathrm{~Pb}_{\mathrm{xs}}\right)$, obtained by subtracting on a layer-by-layer basis the supported fraction (in equilibrium with ${ }^{226} \mathrm{Ra}$ ) presented the same trends of variation as total ${ }^{210} \mathrm{~Pb}$ and did not drop to zero in the basal layers. Therefore, these cores (St-1 and St-2) were qualified as incomplete and disturbed, and were excluded from calculations of sedimentation rates, ages and total inventories of ${ }^{210} \mathrm{~Pb}_{\mathrm{xs}}$. As mentioned before, St-1 and St-2 belong to an area characterised by intensive human activity (navigation, fishing and land-based industrial and commercial facilities) inducing physical disturbances in the sediment. On the other hand, ${ }^{226} \mathrm{Ra}$ at St-3 showed an atypical distribution with depth, especially at $10-12 \mathrm{~cm}$ and the basal three layers where the corresponding activities exceeded unexpectedly total ${ }^{210} \mathrm{~Pb}$, introducing then difficulties in estimating unsupported ${ }^{210} \mathrm{~Pb}$. Such behavior (Ra-226>Pb210) was also observed in other studies in the up-core layers (Ravichandran et al., 1995) and attributed to the 

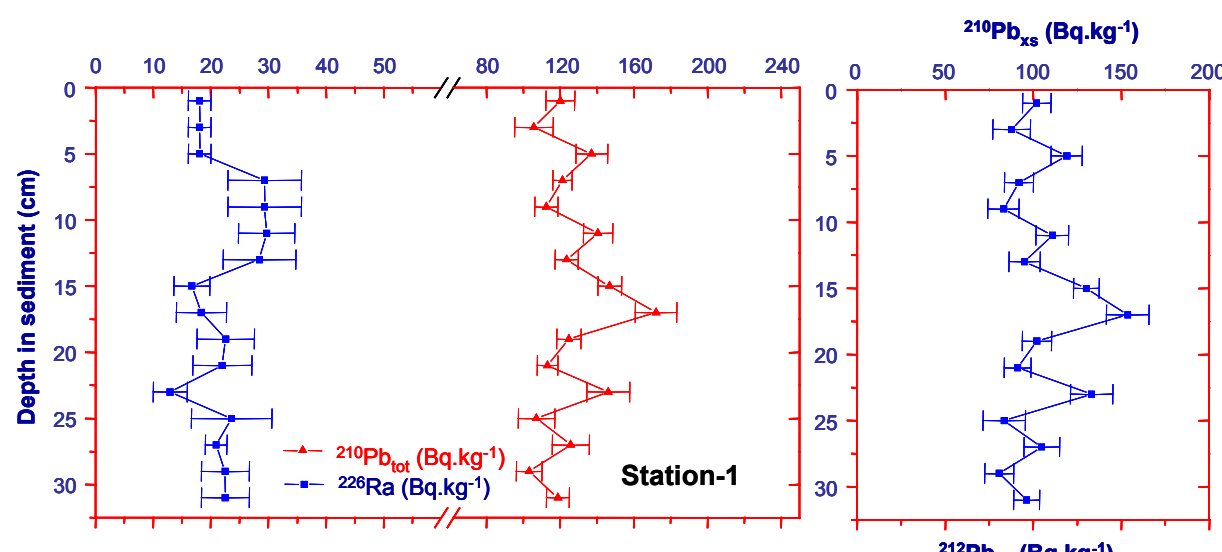

Fig. 5. ${ }^{226} \mathrm{Ra}$, total ${ }^{210} \mathrm{~Pb}$ and ${ }^{210} \mathrm{~Pb}$ xs 00 activity profiles in the sediment cores collected from the Bonny Estuary. Activities, with 1- $\sigma$ statistical errors, are all in $B q \cdot \mathrm{kg}^{-1}$ dry weight and line are only for guidance.
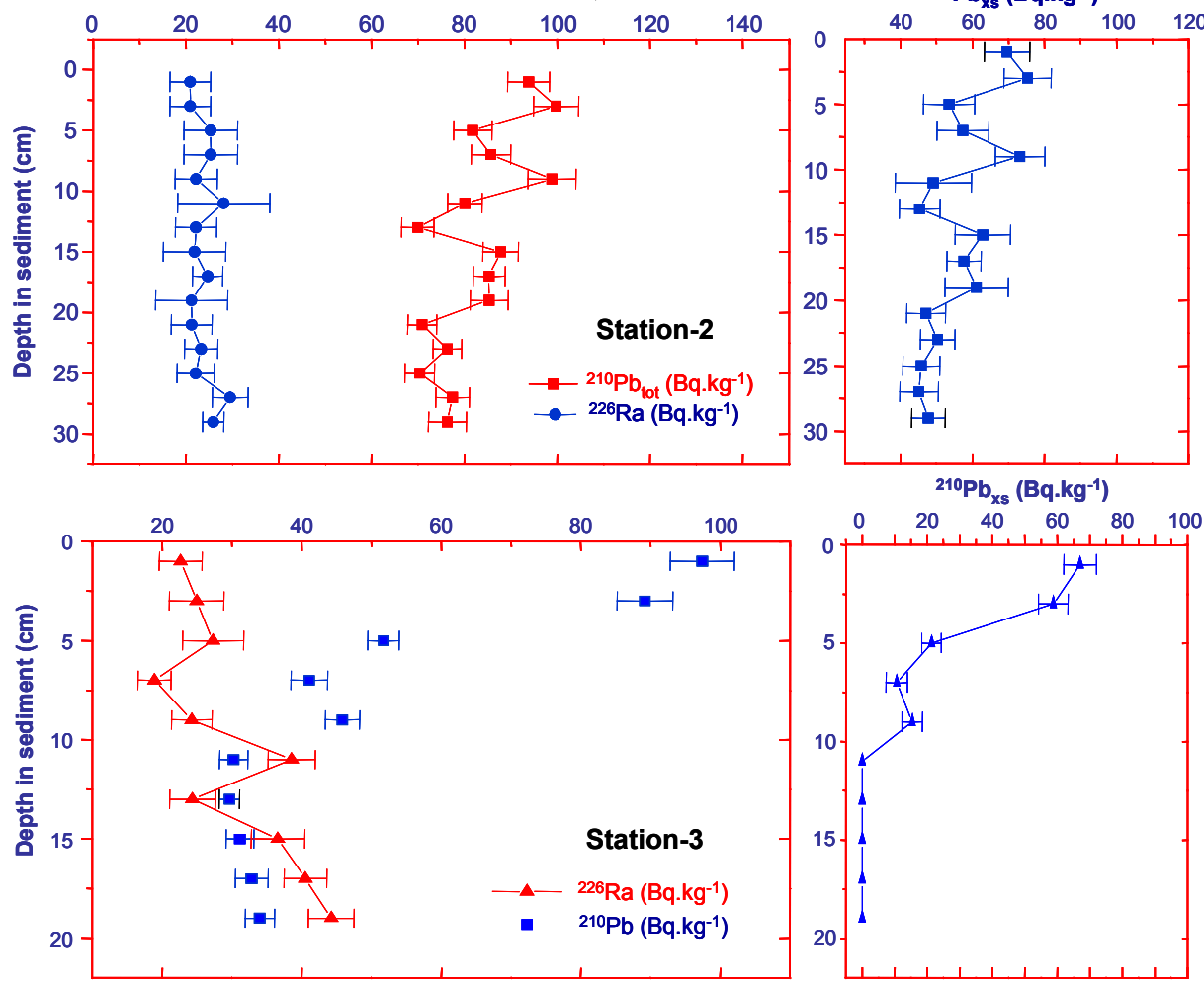

incorporation to the sediment of Ra-enriched material, and to $\mathrm{Rn}-222$ escape. This disequilibrium could be partially correlated to the organic matter content (OMC plotted in Fig. 4) in these layers, since ${ }^{226} \mathrm{Ra}$ activity increases as OMC decreases, but evidently, the profiles at St-1 and St-2 did not exhibit any pattern of variation with OMC.

The presence of ${ }^{226} \mathrm{Ra}$ at concentrations larger than total ${ }^{210} \mathrm{~Pb}$ could be a result of several factors. First, it is well known that $\mathrm{Ra}$ is relatively soluble, especially in brackish and saline waters, so that sediment pore waters are usually enriched in Ra isotopes. Enhanced levels of $\mathrm{Ra}$ were expected in the study area due to the massive pumping upwards of Ra-enriched particles with formation water during oil exploration (Kolb and Wojcik, 1985), which began in early 1900. It is therefore possible that dissolved Ra in interstitial water had enough time to diffuse down-core and, then, enhance its concentration in deeper layers. Second, it was stated that ${ }^{226} \mathrm{Ra} /{ }^{210} \mathrm{~Pb}$ disequilibrium could be a result of supported ${ }^{210} \mathrm{~Pb}$ depletion caused by radon escape (Imboden and Stiller, 1982; Ravichandran et al., 1995). However, in our case only deep layers were affected by this disequilibrium so that radon escape is unlikely to be the major reason. Third, as ${ }^{210} \mathrm{~Pb}$ and ${ }^{226} \mathrm{Ra}$ were measured by means of two independent techniques (alpha and gamma spectrometry, respectively), variations in grain size distributions could be a potential source of error in alpha spectrometry (Zaborska et al., 2007). Indeed, ${ }^{210} \mathrm{~Pb}$ activity concentrations were determined in small aliquots $(<0.5 \mathrm{~g})$, which could have possibly introduced underestimations due to grain size effect 
(i.e. two analyzed aliquots of the same sample may lead to relatively different concentrations).

\section{${ }^{210} \mathrm{~Pb}$ dating of the core from $\mathrm{St}-3$}

In the case of the core collected at St-3, a special assumption was made in an attempt to apply conventional dating models. Unsupported ${ }^{210} \mathrm{~Pb}$ activity is commonly determined by subtracting ${ }^{226} \mathrm{Ra}$ activity, assumed to be in equilibrium with supported ${ }^{210} \mathrm{~Pb}$, from total ${ }^{210} \mathrm{~Pb}$ measured at each stratigraphic level. However, in many studies, estimation of unsupported ${ }^{210} \mathrm{~Pb}$ is usually carried out successfully from the mean total ${ }^{210} \mathrm{~Pb}$ activity at depths where ${ }^{210} \mathrm{~Pb}$ activity is constant (Schelske et al., 1994, Brenner et al., 2004, Tylmann, 2004). In this way, the core ST3 was dated by using only ${ }^{210} \mathrm{~Pb}$ measurements since a constant level of this radionuclide was found below $10 \mathrm{~cm}$ depth. Thus, the averaged activity of the five down-core layers was subtracted from measured total ${ }^{210} \mathrm{~Pb}$ activity at each depth in the core to obtain the excess ${ }^{210} \mathrm{~Pb}$ profile plotted in Fig. 5. The total inventory (the sum of the product of activity, bulk density and thickness of each section) was $1597 \pm 82 \mathrm{~Bq} \cdot \mathrm{m}^{-2}$, much lower than the partial inventories for St-1 and St-2 cores $\left(>22.10^{3} \mathrm{~Bq} \cdot \mathrm{m}^{-2}\right.$ for St- 1 and $>10^{4}$ for St-2). These differences in inventories from one site to another could be attributable to horizontal transport within the estuary and, in major extent, to the variability in sedimentation rates at specific sites (Heltz et al., 1985). Only a small fraction of atmospherically derived ${ }^{210} \mathrm{~Pb}$ was deposited with particles at St-3. The annual flux of ${ }^{210} \mathrm{~Pb}_{\mathrm{xs}}$ onto sediment at St-3, calculated as the product of $\lambda$, the decay constant of ${ }^{210} \mathrm{~Pb}$, and the total inventory, was $49.6 \pm 2.5 \mathrm{~Bq} \cdot \mathrm{m}^{-2} \cdot \mathrm{y}^{-1}$.

Unsupported ${ }^{210} \mathrm{~Pb}$ has been widely and successfully used as a chronometer in sediment geochronological studies (see for instance Laissaoui et al., 2008). The CSR model (Constant rate of supply) and CIC model (Constant Initial Concentration) were applied to the ${ }^{210} \mathrm{~Pb}_{\mathrm{xs}}$ profile of the core collected at St-3. The CRS model assumes that the input of excess ${ }^{210} \mathrm{~Pb}$ to the sediment at a given location is quite uniform over a period of time at least close enough to the age of the core. A full description of the methodology using ${ }^{210} \mathrm{~Pb}$ in sediment chronologies can be seen in Appleby and Oldfield (1992), and examples of potentials and limitations of conventional dating models is given in Kirchner (2011). The CRS model was applied successfully, and calculated ages and sedimentation rates for each stratigraphic level are depicted In Fig. 6. Sedimentation rate have fluctuated over the last $\sim 70$ years due to anthropogenic activities in the surrounding area. A single relatively fast sedimentation $\left(0.109 \pm 0.004 \mathrm{~g} \cdot \mathrm{cm}^{-2} \cdot \mathrm{y}^{-1}\right)$ was recorded for a depth of $2-$ $4 \mathrm{~cm}$ in the core which could be explained as an effect of acceleration in sedimentation rate due to physical processes. Unlike St-1 and St-2, sediment accumulation at St-3 is relatively low $\left(0.124 \mathrm{~cm} \cdot \mathrm{y}^{-1}\right)$ because of the long distance (about $3 \mathrm{~km}$ ) to the nearest site of intensive hu- man activity. Nevertheless, high resolution core is required for a better quantitative description of historical sedimentation in this area.

The CIC model was also applied for comparison purposes. ${ }^{210} \mathrm{~Pb}_{\mathrm{xs}}$ activities were fitted to an exponential decay (Fig. 7). The quality of the least-square fitting was
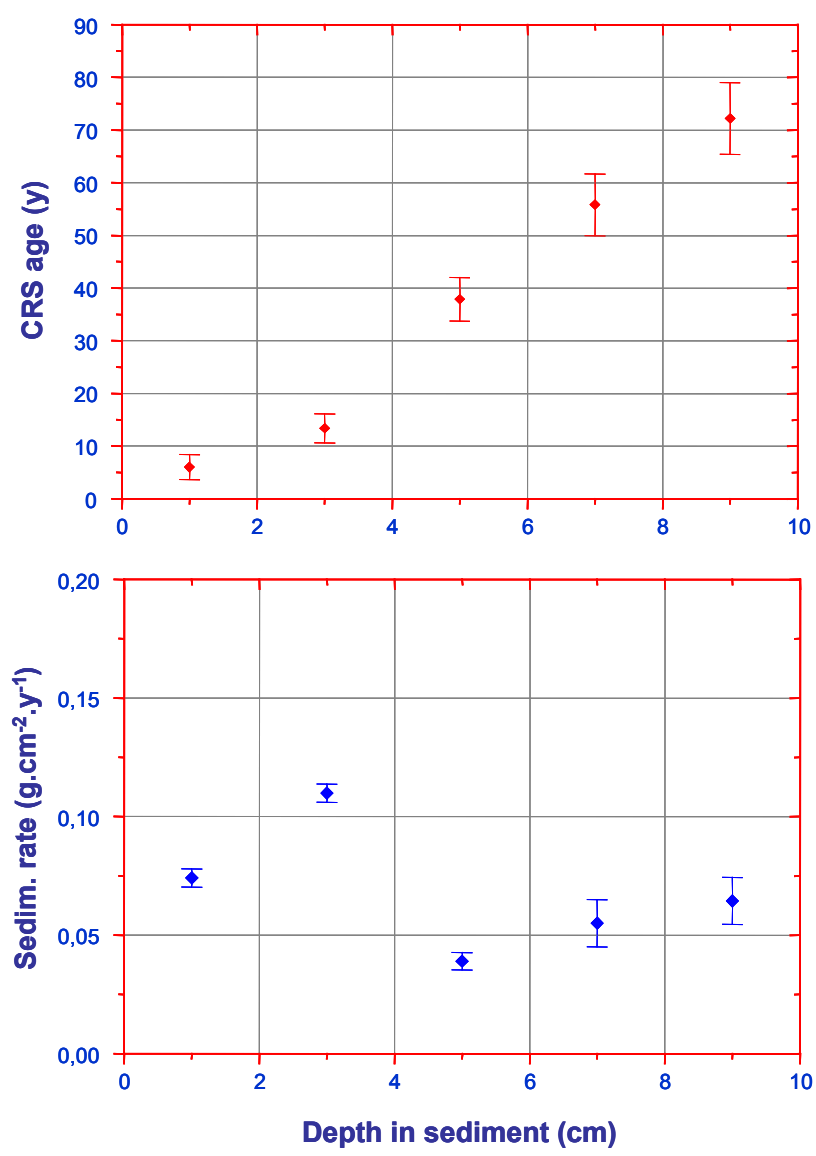

Fig. 6. Age/depth and sedimentation rate/depth relationships determined by CRS model for the sediment core at St-3.

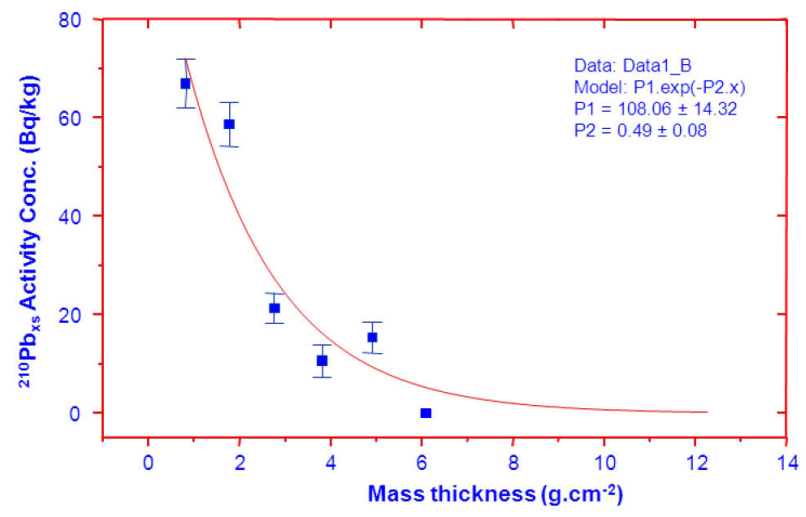

Fig. 7. Excess ${ }^{210} \mathrm{~Pb}$ versus mass thickness for the core St-3. The line is the best fitting to an exponential decay. 
poor $\left(\chi^{2}=43\right)$ and, consequently, the stratigraphic ages provided by this model were quite different from those calculated by the CRS model for some layers. The CIC sedimentation rate was $0.064 \pm 0.004 \mathrm{~g} \cdot \mathrm{cm}^{-2} \cdot \mathrm{y}^{-1}$ and was within the range of the values found throughout the core using the CRS model.

${ }^{210} \mathrm{~Pb}$ chronology should be confirmed by a second independent tracer. ${ }^{137} \mathrm{Cs}$, which is an artificial radionuclide resulting from nuclear bomb testing and detonations since early 1945 , can be used to identify the period of maximum atmospheric fallout. However, deposition of this radionuclide has been recognized, through comprehensive compilation of its global fallout, to be different in the northern and southern hemispheres (Pfitzner et al., 2004). It was expected, therefore, that ${ }^{137} \mathrm{Cs}$ activity concentrations in our sediment samples from the Bonny Estuary, being a tropical area, were relatively low. Effectively, ${ }^{137} \mathrm{Cs}$ in the sub-samples of the core collected at St-3, as shown in Table 1, were below or slightly above the limit of detection of our detection system (HPGe gamma spectrometer of $70 \%$ of relative efficiency). According to the CRS ages, the period of maximum fallout (1963) should be at $6-8 \mathrm{~cm}$ depth in the core. The measured activity in this layer was $1.42 \pm 0.12 \mathrm{~Bq} \cdot \mathrm{kg}^{-1}$, higher than the activity of the immediate below layer, $8-10 \mathrm{~cm}$, which was $<\mathrm{LD}=1.24 \mathrm{~Bq} \cdot \mathrm{kg}^{-1}$. It should be considered that the activity measured in the $6-8 \mathrm{~cm}$ layer is the mean value of activities of a number of thin layers deposited during a period of about 15 years according to CRS model. Thus, the $2 \mathrm{~cm}$ thickness is itself a layered structure due to the low sedimentation rate $\left(0.124 \mathrm{~cm} \cdot \mathrm{y}^{-1}\right)$, and, thus, the maximum activity corresponding to 1963 is diluted in the surrounding sediment of relatively low ${ }^{137} \mathrm{Cs}$ content. On the other hand, activities of the above layers $(0-2,2-4$ and $4-6 \mathrm{~cm}$ ) were both undetectable due to the low amount of the analysed material, and the corresponding limits of detection were higher than the activity concentration of $6-8 \mathrm{~cm}$ depth. This, in addition to the low core resolution $(2 \mathrm{~cm})$, introduced serious difficulties in identifying the depth of the peak associated to atmospheric weapons testing. Nevertheless, ${ }^{137} \mathrm{Cs}$ activities measured individually in the basal $10 \mathrm{~cm}$ of the core were all below $\mathrm{LD}=1.20 \mathrm{~Bq} \cdot \mathrm{kg}^{-1}$, and less than $0.70 \mathrm{~Bq} \cdot \mathrm{kg}^{-1}$ when combined together. Such a finding put in evidence that the sediment below $10 \mathrm{~cm}$ depth in the $\mathrm{St}-3$ core, where no ${ }^{137} \mathrm{Cs}$ activity could be observed, was deposited before the beginning of the period of nuclear detonations, in perfect agreement with CRS ages (before 1940). If there is any ${ }^{137} \mathrm{Cs}$ in these layers, it could be explained by one or a combination of two factors: i) its desorption from the overlaying sediment particles and its diffusion into deeper sediment; the distribution coefficient of Cs is about two to three orders of magnitude lesser than that of highly reactive particles such as $\mathrm{Pu}$ and Am (IAEA, 2004); and ii) cross contamination among layers during coring operation.
Table 1. ${ }^{137} \mathrm{Cs}$ activities, in Bq. $\mathrm{kg}^{-1}$ dry weight, in the samples of the core collected at St-3. LD is limit of detection. Sample 10-20 cm was obtained by combining all sub-samples of $2 \mathrm{~cm}$ thickness.

\begin{tabular}{ccc}
\hline & ${ }^{137}$ Cs Act. $\left(\mathrm{Bq}^{\prime} \mathbf{k g}^{-1}\right)$ & $\mathrm{LD}\left(\mathrm{Bq} \cdot \mathbf{k g}^{-1}\right)$ \\
\hline $0-2$ & $<\mathrm{LD}$ & 1.496 \\
$2-4$ & $<\mathrm{LD}$ & 1.521 \\
$4-6$ & $<\mathrm{LD}$ & 1.825 \\
$6-8$ & $1.416 \pm 0.112$ & -- \\
$8-10$ & $<\mathrm{LD}$ & 1.240 \\
$10-20 \mathrm{~cm}$ & $<\mathrm{LD}$ & 0.702 \\
\hline
\end{tabular}

\section{CONCLUSION}

In this work we studied radionuclide distributions in surface samples collected at different months and locations and in three sediment cores retrieved from sites of diverse sedimentary patterns within the upper Bonny Estuary. ${ }^{210} \mathrm{~Pb}$ activities were found relatively lower in one site (St-3) than in the two others (St-1 and St-2) due to differences in sedimentation rates. In general, no significant enhancement of radionuclide concentrations was detected in the study area. Vertical distributions of radionuclides throughout the three cores were almost homogenous with some exceptions; ${ }^{210} \mathrm{~Pb}$ showed some variability, such as visible decrease with depth at St-3, while the most striking result is an extraordinary increase in deep layers of the same core of ${ }^{226} \mathrm{Ra}$ activities, exceeding total ${ }^{210} \mathrm{~Pb}$ activity concentrations. Therefore, only this core could be dated after making a special assumption. ${ }^{137} \mathrm{Cs}$, whose activities were around $1.3 \mathrm{~Bq} \cdot \mathrm{kg}^{-1}$, was used as an independent tracer for chronology validation. Unfortunately, and due to the low amount of material analysed, in addition to the poor core resolution $(2 \mathrm{~cm})$, it was impossible to identify the depth of the peak of maximum ${ }^{137} \mathrm{Cs}$ fallout. But the age/depth relationship provided by CRS dating model was in good agreement with the undetectable levels of ${ }^{137} \mathrm{Cs}$ reported for the $10 \mathrm{~cm}$ bottom of the core, which constitutes a qualitative validation of the chronology established from the decay of excess ${ }^{210} \mathrm{~Pb}$. Nevertheless, high core resolution is required for more accurate dating and validation, and it is advisable to use another time-marker such as Plutonium.

The levels of radionuclide activities reported in this paper are the first such a data in the Upper Bonny Estuary and, therefore, the results should be of interest for future radioactive monitoring efforts.

\section{ACKNOWLEDGMENT}

This work was carried out within the framework of the International Atomic Energy Agency Regional Project RAF/7/009 "Supporting an Integrated Approach for Marine Pollution Monitoring using Nuclear Analytical Techniques". The authors would like to thank the Moroccan authorities for hosting the fellowship "Marine Envi- 
ronment and Coastal Zone Management" at the Centre National de l'Energie, des Sciences et des Techniques Nucléaires.

\section{REFERENCES}

Arogunjo AM, Hollriegl V, Giussani A, Leopold K, Gerstmann U, Veronese I and Oeh U, 2009. Uranium and thorium in soils, mineral sands, water and food samples in a tin mining area in Nigeria with elevated activity. Journal of Environmental Radioactivity 100(3): 232-240, DOI 10.1016/j.jenvrad.2008.12.004.

Agbalagba EO and Enoja RA, 2011. Evaluation of natural radioactivity in soil, sediment and water samples of Niger Delta (Biseni) flood plain lakes, Nigeria. Journal of Environmental Radioactivity 102(7): 667-671, DOI 10.1016/j.jenvrad.2011.03.002.

Alatise OO, Babalola IA and Olowofela JA, 2008. Distribution of some natural gamma-emitting radionuclides in the soils of the coastal areas of Nigeria. Journal of Environmental Radioactivity 99(11): 1746-1749, DOI 10.1016/j.jenvrad.2008.06.014.

Appleby PG and Oldfield F, 1992. Application of 210-lead to sedimentation studies. In: Ivanovich, M., Harmon, R.S. (Eds.), Uranium Series Disequilibrium: Appplications to Earth, Marine and Environmental Sciences, second ed. Oxford Science, Oxford, pp. 731783.

Appleby PG, 2008. Three decades of dating recent sediments by fallout radionuclides: a review. The Holocene 18(1): 83-93, DOI $10.1177 / 0959683607085598$.

Begy R, Timar-Gabor A, Somlai J and Cosma C, 2011. A sedimentation study of St. Ana Lake (Romania) applying the ${ }^{210} \mathrm{~Pb}$ and ${ }^{137} \mathrm{Cs}$ dating methods. Geochronometria 38(2): 93-100, DOI 10.2478/s13386-011-0017-6.

Brenner M, Claire L, Schelske CL and William FK, 2004. Inputs of dissolved and particulate ${ }^{226} \mathrm{Ra}$ to lakes and implications for ${ }^{210} \mathrm{~Pb}$ dating recent sediments. Journal of Paleolimnology 32(1): 53-66, DOI 10.1023/B:JOPL.0000025281.54969.03.

Dublin-Green CO, 1985. Some textural characteristics and organic matter contents of recent sediments in the Bonny Estuary, Niger Delta. Technical Paper $\mathrm{N}^{\circ}$ 67. ISBN: 978-2345-069.

Farai IP, Obed RI and Jibiri NN, 2006. Soil radioactivity and incidence of cancer in Nigeria. Journal of Environmental Radioactivity 90(1): 29-36, DOI 10.1016/j.jenvrad.2006.06.003.

Helz GR, Setlock GH, Cantillo AY, Moore WS, 1985. Processes controlling the regional distribution of ${ }^{210} \mathrm{~Pb},{ }^{226} \mathrm{Ra}$ and anthropogenic zinc in estuarine sediments. Earth and Planetary Science Letters 76(1-2): 23-34, DOI 10.1016/0012-821X(85)90145-1.

Imboden DM and Stiller M, 1982. Influence of radon diffusion on the ${ }^{210} \mathrm{~Pb}$ distribution in sediments. Journal of Geophysical Research: Oceans 87: 557-565, DOI 10.1029/JC087iC01p00557.

International Atomic Energy Agency, 2004. Sediment Distribution Coefficients and Concentration Factors for Biota in the Marine Environment. Technical Reports Series ISSN 0074-1914; no. 422.

Inyang IR, Adeyemo AO and Ogamba EN, 2011. Impact of Waste Dump on Seasonal Fish Species Composition and Water Quality in the Upper Bonny Estuary. International Journal of Current Biological and Medical Science 1(3): 90-94.

Kirchner G, 2011. ${ }^{210} \mathrm{~Pb}$ as a tool for establishing sediment chronologies: examples of potentials and limitations of conventional dating models. Journal of Environmental Radioactivity 102(5): 490-494, DOI 10.1016/j.jenvrad.2010.11.010.

Kolb WA and Wojcik M, 1985. Enhanced radioactivity due to natural oil and gas production and related radiological problems. Science of the Total Environment 45: 77-84, DOI 10.1016/00489697(85)90206-2.

Laissaoui A, Benmansour M, Ziad N, IbnMajah M, Abril JM and Mulsow S, 2008. Anthropogenic radionuclides in the water column and a sediment core from the Alboran Sea: Application to radiometric dating and reconstruction of historical water column radionuclide concentration. Journal of Paleolimnology 40(3): 823833, DOI 10.1007/s10933-008-9201-y.

Laissaoui A, Mas JL, Hurtado S, Ziad N, Villa M and Benmansour M, 2013. Radionuclide activities and metal concentrations in sediments of the Sebou Estuary, NW Morocco, following a flooding event. Environmental Monitoring and Assessment 185(6): 50195029, DOI 10.1007/s10661-012-2922-4.

Leopold K and Gerstmann U, 2009. A comment on "Distribution of some natural gamma-emitting radionuclides in the soils of the coastal areas of Nigeria" by Alatise, O.O., Babalola, I.A. \& Olowofela, J.A. Journal of Environmental radioactivity, 99 (2008) 1746-1749. Letter to Editor. Journal of Environmental radioactivity 100(7): 605, DOI 10.1016/j.jenvrad.2009.03.019.

Matthews KM, Kim CK and Martin P, 2007. Determination of ${ }^{210} \mathrm{Po}$ in environmental materials: A review of analytical methodology. Applied Radiation and Isotopes 65(3): 267-279, DOI 10.1016/j.apradiso.2006.09.005.

Noakes S, 2003. Postdisposal areal mapping of sediment chemistry at the Fort Pierce, Florida ODMDS. U.S. Environmental Protection Agency, Final Report.

Pfitzner J, Brunskill G and Zagorskis I, 2004. ${ }^{137} \mathrm{Cs}$ and excess ${ }^{210} \mathrm{~Pb}$ deposition patterns in estuarine and marine sediment in the central region of the Great Barrier Reef Lagoon, north-eastern Australia. Journal of Environmental Radioactivity 76(1-2): 81-102, DOI 10.1016/j.jenvrad.2004.03.020.

Ravichandran M, Baskaran M, Santschi PH and Bianchi TS, 1995. Geochronology of sediments in the Sabine-Neches estuary, Texas, USA. Chemical Geology 125(3-4): 291-306, DOI 10.1016/00092541(95)00082-W.

Schelske CL, Peplow A, Brenner M and Craig N, 1994. Lowbackground gamma counting: applications for ${ }^{210} \mathrm{~Pb}$ dating of sediments. Journal of Paleolimnology 10(2): 115-128, DOI 10.1007/BF00682508.

Szczepańska A, Zaborska A, Maciejewska A and Kuliński K, 2012. Distribution and origin of organic matter in the Baltic Sea sediments dated with ${ }^{210} \mathrm{~Pb}$ and ${ }^{137} \mathrm{Cs}$. Geochronometria 39(1): 1-9, DOI 10.2478/s13386-011-0058-x.

Tylmann W, 2004. Estimating recent sedimentation rates using ${ }^{210} \mathrm{~Pb}$ on the example of morphologically complex lake (Upper Lake Raduñskie, N Poland). Geochronometria 23: 21-26.

United Nations Scientific Committee on Effects of Atomic Radiation, 2000. Exposures from Natural Radiation Sources, UNSCEAR Report, New York.

Zaborska, A, Carroll J, Papucci C and Pempkowiak J, 2007. Intercomparison of alpha and gamma spectrometry techniques used in $210 \mathrm{~Pb}$ geochronology. Journal of Environmental Radioactivity 93(1): 38-50, DOI 10.1016/j.jenvrad.2006.11.007. 